\title{
VOLATILITAS HARGA SAHAM: LEVERAGE, UKURAN PERUSAHAAN, PERTUMBUHAN ASET
}

\author{
Hasna Rosyida, Amrie Firmansyah, Setyo Baskoro Wicaksono \\ Politeknik Keuangan Negara STAN, Tangerang Selatan, Indonesia \\ 1401170024.hasnarosyida@gmail.com, amrie.firmansyah@gmail.com, \\ 1401170009.setyobaskoro@gmail.com \\ https://doi.org/10.46367/jas.v4i2.256 \\ Received: Nov 08, 2020 Revised: Nov 23, 2020 Accepted: Dec 04, 2020 Published: Dec 16, 2020
}

\begin{abstract}
This study examines the effect of leverage, company size, and asset growth on stock price volatility. This study uses data from all companies listed on the LQ45 index (BEI) from 2017 to 2019. Based on purposive sampling, this study obtained 31 financial statement data so that the final sample in this study amounted to 93 firmyear observations. Data analysis was analyzed using multiple regression analysis with Eviews 10 software. The study results concluded that leverage has a positive effect on stock price volatility, company size has a negative effect on stock price volatility, and asset growth has no effect on stock price volatility. This study's results can be used as material for management evaluation in increasing share prices so that this condition can attract investors' interest in investing in the company.
\end{abstract}

Keywords: Asset Growth, Firm Size, Leverage, Stock Price Volatility.

\begin{abstract}
ABSTRAK
Penelitian ini bertujuan untuk menguji pengaruh leverage, ukuran perusahaan dan pertumbuhan aset terhadap volatilitas harga saham. Penelitian ini menggunakan data dari seluruh perusahaan yang terdaftar di indeks LQ45 (BEI) selama periode 2017 sampai dengan 2019. Berdasarkan purposive sampling, penelitian ini mendapatkan 31 data laporan keuangan, sehingga sampel final dalam penelitian ini berjumlah 93 observasi (firm-year). Analisis data dianalisis menggunakan analisis regresi berganda dengan software Eviews 10. Hasil penelitian menyimpulkan bahwa leverage berpengaruh positif terhadap volatilitas harga saham, ukuran perusahaan berpengaruh negatif terhadap volatilitas harga saham, dan pertumbuhan aset tidak berpengaruh terhadap volatilitas harga saham. Hasil penelitian ini dapat dijadikan sebagai bahan evaluasi manajemen dalam meningkatkan harga saham, sehingga kondisi ini dapat menarik minat investor dalam berinvetasi di perusahaan tersebut.
\end{abstract}

Kata Kunci: Pertumbuhan Aset, Ukuran Perusahaan, Leverage, Volatilitas Harga Saham.

\section{PENDAHULUAN}

Harga saham terbentuk dari interaksi permintaan dan penawaran. Peningkatan permintaan saham akan mendorong kenaikan harga, demikian pula sebaliknya. Jika investor banyak melakukan penjualan suatu saham maka harga saham akan mengalami penurunan. Hal tersebut menyebabkan harga saham 
mengalami perubahan setiap waktu. Perubahan harga saham tersebut dikenal dengan volatilitas harga saham. Volatilitas harga saham dapat digunakan untuk mengukur risiko suatu saham. Saham yang mengalami volatilitas, mengalami perubahan harga kapan saja dan dan sulit untuk diprediksi. Banyaknya investor lebih memilih saham yang mudah diprediksi dan resikonya kecil karena semakin tinggi volatilitas semakin besar tingkat ketidakpastian untuk mendapatkan return. Oleh karena itu, investor membutuhkan informasi terkait dengan perkembangan harga saham dalam memutuskan investasinya di pasar modal. Hal ini sesuai dengan teori sinyal yang mengemukakan tentang bagaimana seharusnya perusahaan memberikan sinyal-sinyal informasi kepada pengguna laporan keuangan.

Keputusan pendanaan dapat memberikan pengaruh terhadap volatilitas harga saham melalui informasi yang ditimbulkan. Sebagai salah satu kebijakan pendanaan perusahaan, leverage menimbulkan beban atau biaya tetap yang harus di tanggung perusahaan. Penelitian mengenai pengaruh leverage terhadap volatilitas harga saham dilakukan oleh (Jannah and Haridhi 2016; Abrar-ul-haq et al. 2015; Mobarak and Mahfud 2017; Selpiana and Badjra 2018) yang membuktikan bahwa terdapat pengaruh positif leverage terhadap volatilitas harga saham. Hasil penelitian yang berbeda ditunjukkan oleh (Mahdy 2015; Dewi and Suaryana 2016; Ardiansyah and Isbanah 2017) yang menyimpulkan bahwa leverage tidak berpengaruh terhadap volatilitas harga saham.

Sementara itu, ukuran perusahaan diduga dapat memberikan informasi bagi para pelaku pasar modal karena perusahaan yang besar dapat mengelola aktivitas bisnisnya dengan baik. Kondisi ini dapat mempengaruhi sikap investor yang terlihat dari perubahan harga saham perusahaan. Perusahaan besar memiliki akses yang lebih mudah ke pasar modal, sehingga investor meyakini perusahaan besar biasanya akan menghasilkan laba yang besar. Informasi mengenai kinerja perusahaan yang bagus ini akan cepat tersebar kepada publik dan membuat harga saham perusahaan menjadi naik. Oleh karena itu, investor akan merespon kondisi ini dan tercermin dengan harga saham yang stabil. Penelitian mengenai pengaruh ukuran perusahaan terhadap volatilitas harga saham dilakukan oleh (Patriadjati 2017; Surahmat et al. 2017; Andiani and Gayatri 2018; Rusiana and Kusumawati 2019; Marini and Dewi 2019; Yulinda et al. 2020) yang menyimpulkan bahwa ukuran perusahaan berpengaruh negatif terhadap volatilitas harga saham. Adapun penelitian oleh (Abrar-ul-haq et al. 2015; Ardiansyah and Isbanah 2017; Oktavianti and Saryadi 2020) membuktikan bahwa ukuran perusahaan tidak berpengaruh terhadap volatilitas harga saham.

Selain itu, faktor lain yang dapat mempengaruhi volatilitas harga saham adalah pertumbuhan aset. Pertumbuhan aset yang semakin pesat menunjukkan adanya kestabilan kinerja perusahaan. Informasi tersebut diduga digunakan oleh pemegang saham sehingga pemegang saham cenderung akan menunggu perkembangan informasi tersebut perusahaan yang berakibat pemegang saham menahan saham yang dimiliki. Pertumbuhan aset perusahaan yang tinggi erat kaitannya dengan penurunan volatilitas harga saham perusahaan. Penelitian mengenai pengaruh pertumbuhan aset terhadap volatilitas harga saham dilakukan oleh (Mustika 2018) yang membuktikan bahwa pertumbuhan aset berpengaruh positif terhadap volatilitas harga saham. Sementara itu, (Artikanaya and Gayatri 2020) menemukan bahwa pertumbuhan aset berpengaruh negatif terhadap 
volatilitas harga saham. Namun, (Rowena and Hendra 2017; Santioso and Angesti 2019) menemukan bahwa pertumbuhan aset tidak berpengaruh terhadap volatilitas harga saham.

Berdasarkan adanya inkonsistensi hasil pengujian dalam penelitian sebelumnya, penelitian ini bertujuan untuk menguji leverage, ukuran perusahaan, dan pertumbuhan aset terhadap volatilitas harga saham. Data penelitian ini menggunakan data perusahaan Indeks LQ45 yang terdiri dari 45 saham yang mencerminkan saham-saham dengan likuiditas (jumlah hari perdagangan dan frekuensi transaksi) dan kapitalisasi pasar (volume transaksi) yang tinggi. Oleh karena itu, saham-saham perusahaan LQ45 dapat dijadikan sebagai patokan naik turunnya harga saham yang terdaftar di Bursa Efek Indonesia. Selain itu, sahamsaham perusahaan ini merupakan saham-saham yang paling banyak diminati investor di pasar modal Indonesia dan mencakup 75\% kapitalisasi pasar sehingga dapat mewakili saham-saham yang tercatat di Bursa Efek Indonesia.

\section{TELAAH LITERATUR}

\section{Konsep Teori}

Pihak-pihak yang berkaitan dengan perusahaan tidak memiliki informasi yang sama mengenai prospek dan resiko perusahaan (Patriadjati 2017). Pihak tertentu memiliki informasi yang lebih baik dibandingkan pihak lainnya. Manajer biasanya mempunyai informasi yang lebih baik dibanding pihak luar seperti investor. Terkait dengan hal tersebut, teori signalling menjelaskan tentang bagaimana seharusnya sebuah perusahaan memberikan isyarat kepada pengguna laporan keuangan (Patriadjati 2017). Sinyal terkait dengan kebijakan perusahaan tertentu yang memberikan petunjuk bagi investor tentang bagaimana manajemen memandang prospek perusahaan (Dewi and Suaryana 2016). Manajemen perusahaan pada umumnya mempunyai informasi yang lebih baik daripada investor tentang kondisi perusahaan saat ini dan prospeknya di masa mendatang. Teori signalling menjelaskan bahwa pemberian isyarat dilakukan oleh manajer untuk mengurangi asimetri informasi. Informasi yang lengkap, akurat, relevan, dan tepat waktu sangat dibutuhkan oleh investor di pasar modal sebagai alat analisis untuk mengambil keputusan investasi. Informasi dari perusahaan tersebut direspon oleh investor yang kemudian akan mempengaruhi volatilitas harga saham.

Menurut teori pasar efisien bahwa dalam suatu pasar yang efisien, harga akan mencerminkan sepenuhnya informasi yang tersedia dan sebagai implikasinya harga dan akan bereaksi secara seketika tanpa adanya bias terhadap informasi baru (Dissanayake and Wickramasinghe 2016). Dalam pasar efisiensi, harga saham akan selalu berkolerasi atau mencerminkan semua informasi yang ada di pasar (Theresia and Arilyn 2015). Konsep pasar efisien berkaitan dengan hubungan ketersediaan informasi dan harga-harga sekuritas saham (Nasution 2015). Pasar dapat dikatakan efisien apabila nilai sekuritas setiap waktu mencerminkan semua informasi yang tersedia, yang dapat mengakibatkan harga suatu sekuritas berada pada tingkat keseimbangannya. Harga keseimbangan suatu sekuritas mengakibatkan tidak adanya kesempatan yang diperoleh investor untuk mendapatkan return yang abnormal dari selisih harga sekuritas saham. 
Investasi di pasar modal tidak terlepas dari adanya risiko saham. Risiko berkaitan dengan ketidakpastian yang dimiliki investor akan masa depan dan tercermin dalam volatilitas harga saham (Rohmawati 2016). Volatilitas merupakan pengukuran statistik untuk fluktuasi harga saham selama periode tertentu (Rohmawati 2016). Secara umum, volatilitas di pasar keuangan mencerminkan tingkat resiko yang dihadapi investor karena menggambarkan fluktuasi pergerakan harga saham dan ketidakpastian yang dimiliki investor.

Tingkat leverage merupakan suatu kemampuan perusahaan untuk membayar seluruh kewajiban kepada kreditor baik kewajiban jangka pendek maupun jangka panjang. Rasio ini berpengaruh terhadap investor, yang ditandai dengan permintaan akan saham perusahaan tersebut (Mahdy 2015). Leverage berkaitan dengan penggunaan aset dan sumber dana oleh perusahaan yang memiliki biaya tetap dengan maksud agar meningkatkan keuntungan potensial pemegang saham (Jannah and Haridhi 2016). Leverage merupakan alat ukur seberapa besar perusahaan bergantung pada kreditor dalam membiayai aset perusahaan.

Leverage juga menunjukkan bagian dari ekuitas yang dijadikan jaminan untuk keseluruhan utang yang dimiliki perusahaan (Mustika 2018). Ketidakmampuan pencapaian laba dan menutupi utang perusahaan merupakan hal yang tidak diharapkan oleh investor dan mempengaruhi perilaku investor untuk menjual atau membeli saham. Kondisi tersebut dimungkinkan perusahaan yang mempunyai tingkat leverage tinggi berarti sangat bergantung pada pinjaman luar untuk membiayai asetnya, sedangkan perusahaan yang mempunyai tingkat leverage lebih rendah lebih banyak membiayai asetnya dengan modal sendiri. Sebagai salah satu kebijakan pendanaan perusahaan, leverage menimbulkan beban atau biaya tetap yang harus ditanggung perusahaan (Mustika 2018). Leverage memberikan pengaruh terhadap informasi yang di timbulkan. Misalnya reaksi atas bad news menyebabkan penurunan dan good news menyebabkan kenaikan. Perusahaan perlu mengkombinasikan sumber pendanaannya antara modal sendiri dengan utang karena tingkat leverage yang dimiliki oleh perusahaan mencerminkan risiko perusahaan.

Ukuran perusahaan adalah suatu skala untuk mengklasifikasikan besar kecilnya perusahaaan melalui total aktiva, penjualan bersih, dan kapitalisasi pasar perusahaan (market capitalization) (Murniati 2015). Patriadjati (2017) menyatakan bahwa ukuran perusahaan merupakan skala dimana besar atau kecilnya suatu perusahaan, dapat diklasifikasikan berdasarkan total aset perusahaan atau total penjualan Perusahaan dengan ukuran besar akan sangat mudah mengakses pasar modal dan fleksibilitas serta kemampuannya dalam memperoleh dana lebih tinggi dibandingkan dengan perusahaan dengan ukuran kecil (Selpiana and Badjra 2018). Ukuran perusahaan dapat digambarkan melalui total aset perusahaan yang digunakan untuk beroperasi. Tingginya ukuran perusahaan dapat mencerminkan kemudahan dalam akses informasi terkait perusahaan yang diperoleh publik.

Pertumbuhan aset perusahaan berkaitan dengan peningkatan atau penurunan total aset yang dimiliki oleh perusahaan. Selain itu, pertumbuhan aset perusahaan merupakan perubahan (peningkatan atau penurunan) total aset yang dimiliki oleh perusahaan. Perusahaan dengan tingkat pertumbuhan aset perusahaan yang cepat harus lebih banyak mengandalkan dana eksternal untuk 
tujuan pembiayaan ekspansi. Pertumbuhan aset perusahaan pada dasarnya menggambarkan bagaimana perusahaan menginvestasikan dana yang perusahaan miliki untuk kegiatan operasi dan investasi.

Selanjutnya, pertumbuhan aset merupakan indikator seberapa banyak perusahaan memaksimalkan penggunaan dana dari sumber modal (Patriadjati 2017). Perusahaan yang sedang dalam tahap berkembang akan cenderung menggunakan laba untuk diinvestasikan kembali daripada membagikannya pada investor (Patriadjati 2017). Oleh karena itu, pertumbuhan aset dapat didefinisikan sebagai peningkatan atau penurunan total aset yang dimiliki oleh perusahaan yang menggambarkan seberapa besar perusahaan menginvestasikan dana yang ia miliki untuk kegiatan operasi.

\section{Pengembangan Hipotesis}

Leverage menunjukkan pendanaan perusahaan yang bersumber dari utang (Fahmi 2016). Leverage mengukur kemampuan perusahaan dalam menutupi sebagian atau seluruh utangnya baik jangka panjang maupun jangka pendek. Oleh karena itu, tingkat leverage dapat menimbulkan risiko perusahaan khususnya potensi kebangkrutan perusahaan di masa mendatang. Leverage erat kaitannya dengan kebijakan pilihan pendanaan pembiayaan oleh perusahaan. Informasi leverage yang terdapat dalam laporan keuangan dapat menunjukkan sinyal tertentu perusahaan kepada publik khususnya investor.

Penelitian (Abrar-ul-haq et al. 2015; Jannah and Hariadhi 2016; Mobarak and Mahfud 2017; Selpiana and Badjra 2018) menemukan bahwa leverage berpengaruh positif signifikan terhadap volatilitas harga saham. Hasil temuan tersebut menunjukkan bahwa ketika perusahaan melakukan pendanaan lebih banyak dengan menggunakan utang dapat mendorong tingkat risiko yang diterima oleh perusahaan. Adanya informasi tersebut yang diterima oleh investor menunjukkan bahwa penggunaan pendanaan utang yang lebih banyak cenderung dapat meningkatkan potensi kesulitan keuangan perusahaan di masa mendatang. Oleh karena itu, kondisi ini dapat tercermin dari ketidakstabilan harga saham di pasar modal. Dengan demikian, hipotesis penelitian yang pertama adalah $\mathrm{H}_{1}$ : Leverage berpengaruh positif terhadap volatilitas harga saham.

Perusahaan yang besar memiliki ketidakseimbangan informasi yang kecil sehingga informasi dapat dengan jelas diserap dan dianalisa oleh investor (Patriadjati 2017). Aset perusahaan yang besar akan dipandang oleh investor sebagai bentuk tingkat kemapanan perusahaan yang berdampak stabilnya harga saham. Di lain sisi, perusahaan kecil cenderung dianggap kurang mapan oleh investor, sehingga investor tidak terlalu percaya berinvestasi di saham-saham perusahaan kecil. Kondisi berdampak dengan ketidakstabilan harga saham di pasar modal. Informasi besarnya perusahaan dapat diperoleh dari laporan keuangan perusahaan sehingga respon informasi tersebut oleh pasar erat kaitannya dengan teori pasar efisien semi kuat.

Penelitian (Patriadjati 2017; Surahmat et al. 2017; Andiani and Gayatri 2018; Rusiana and Kusumawati 2019; Marini and Dewi 2019; Yulinda et al. 2020) menemukan bahwa ukuran perusahaan berpengaruh negatif terhadap volatilitas harga saham. Besarnya perusahaan dianggap memiliki kebijakan yang lebih stabil dalam menentukan masa depan perusahaan. Oleh karena itu, investor yang mengetahui informasi ukuran perusahaan dari laporan keuangan merasa 
lebih yakin untuk berinvestasi di perusahaan-perusahaan yang cenderung besar. Keputusan tersebut diambil dengan harapan bahwa investor membutuhkan tingkat pengembalian yang pasti dengan risiko yang lebih kecil. Dengan demikian, hipotesis penelitian yang kedua adalah $\mathrm{H}_{2}$ : Ukuran perusahaan berpengaruh negatif signifikan terhadap volatilitas harga saham.

Perusahaan yang sedang dalam tahap berkembang memiliki arus kas bebas yang minim karena sebagian besar dana hasil dari keuntungan perusahaan lebih digunakan untuk membiayai proyek yang memiliki nilai bersih saat ini yang positif (Patriadjati 2017). Manajer perusahaan berkembang lebih memilih menginvestasikan pendapatan setelah pajak dan memiliki harapan kinerja yang lebih baik dalam pertumbuhan aset secara keseluruhan. Perusahaan yang sedang dalam tahap berkembang akan cenderung menggunakan laba untuk diinvestasikan kembali daripada membagikannya pada investor (Patriadjati 2017). Namun, informasi ini dapat digunakan oleh investor sebagai sinyal bahwa perusahaan tersebut memiliki kepastian masa depan yang tinggi.

Artikanaya and Gayatri (2020) menemukan bahwa pertumbuhan aset berpengaruh negatif terhadap volatilitas harga saham. Pertumbuhan aset dapat dihubungkan dengan tingkat prospektifitas suatu perusahaan tersebut. Perusahaan dengan pertumbuhan aset yang tinggi tentu akan semakin efisien dalam melakukan kegiatan produksi. Semakin besar aset diharapkan semakin besar pula tingkat hasil operasional suatu perusahaan. Pertumbuhan aset yang diikuti oleh pertumbuhan hasil operasional akan semakin menambah kepercayaan investor terhadap prospek di masa mendatang suatu perusahan. Semakin tinggi kepercayaan investor terhadap suatu perusahaan maka akan semakin panjang pula periode investor dalam menahan saham tersebut untuk tidak dijual. Respon investor tersebut dapat tercermin dalam tingkat harga saham yang lebih stabil. Oleh karena itu, hipotesis penelitian yang ketiga adalah $\mathrm{H}_{3}$ : Pertumbuhan aset berpengaruh negatif terhadap volatilitas harga saham.

\section{METODE PENELITIAN}

Penelitian ini menggunakan data dari seluruh perusahaan yang terdaftar di indeks LQ45 (BEI) selama periode 2017 sampai dengan 2019. Pemilihan objek ini didasarkan untuk menghindari pengambilan sampel yang berpotensi mengikutsertakan saham tidak aktif. Saham perusahaan yang masuk perhitungan indeks LQ45 merupakan saham-saham dengan kapitalisasi besar yang mencakup 75\% kapitalisasi pasar sehingga dapat mewakili saham-saham yang tercatat di Bursa Efek Indonesia. Pemilihan sampel dilakukan dengan menggunakan purposive sampling dengan mengeliminasi populasi yang memiliki kriteriakriteria. Kriteria pertama, yakni perusahaan terdaftar di indeks LQ-45 secara konsisten mulai tahun 2017-2019. Kriteria kedua adalah perusahaan mempublikasikan laporan keuangan tahunan yang telah diaudit dari tahun 20172019 secara berturut-turut serta laporan keuangan disajikan dalam mata uang Rupiah. Kriteria ketiga, yakni perusahaan memiliki informasi secara lengkap sesuai dengan apa yang dibutuhkan peneliti dalam pengukuran variabel. Berdasarkan kriteria-kriteria yang telah ditetapkan tersebut semua data diseleksi sehingga perusahaan yang digunakan sebagai sampel dalam penelitian ini 
berjumlah 31, sehingga sampel final penelitian ini berjumlah 93 observasi (firmyear).

Variabel dependent dalam penelitian ini adalah volatilitas harga saham, sedangkan variabel independent terdiri dari leverage, ukuran perusahaan, dan pertumbuhan aset. Volatilitas harga saham merupakan pengukuran statistik untuk fluktuasi harga selama periode tertentu. Semakin tinggi volatilitas, maka potensi return akan semakin tinggi. Volatilitas yang rendah menunjukkan kestabilan nilai return, akan tetapi umumnya returnnya tidak terlalu tinggi. Proksi volatilitas harga saham dalam penelitian ini mengikuti (Waluyo 2016), yaitu sebagai berikut:

$$
\mathrm{PV}=\sqrt{\frac{1}{n} \sum \ln \left(\frac{H t}{L t}\right)^{2}}
$$

Dimana:

PV : Volatilitas harga saham

$\mathrm{Ht}$ : Harga saham tertinggi pada periode $\mathrm{t}$

Lt : Harga saham terendah pada periode $\mathrm{t}$

$\mathrm{N} \quad$ : Jumlah observasi

Pada penelitian ini leverage diukur dengan debt to equity ratio (DER), yakni menggunakan total hutang jangka panjang dan jangka pendek dengan total ekuitas perusahaan sebagaimana penelitian (Jannah and Haridhi 2016p; Bahrun et al. 2020; Salman et al. 2020; Pajriansyah and Firmansyah 2017; Firmansyah and Yunidar 2020), yaitu sebagai berikut:

$$
D E R=\frac{\text { Total Debt }}{\text { Total Equity }}
$$

Ukuran perusahaan diproksikan dengan menggunakan Log Natural Total Aset sebagaimana penelitian (Rusiana and Kusumawati 2019; Firmansyah and Herawaty 2016) yaitu sebagai berikut:

\section{SIZE = Logaritman Natural (Ln) Total Assets}

Pertumbuhan aset (growth) didefinisikan sebagai perubahan tahunan dari total aset. Pertumbuhan aset merupakan indikator seberapa besar perusahaan itu menggunakan dananya. Dalam penelitian ini, pertumbuhan aset mengikuti proksi yang digunakan oleh (Mustika 2018) yaitu sebagai berikut:

$$
\text { GROWTH }=\frac{\text { Total aset akhir tahun }- \text { Total aset awal tahun }}{\text { Total aset awal tahun }}
$$

Analisis data dalam penelitian ini menggunakan analisis regresi data panel. Model penelitian utama pada penelitian ini adalah sebagai berikut:

$$
\mathrm{PV}_{\mathrm{it}}=\alpha+\beta 1 \mathrm{DER}_{\mathrm{it}}+\beta 2 \mathrm{SIZE}_{\mathrm{it}}+\beta 3 \mathrm{GROWTH}_{\mathrm{it}}+\mathrm{e}_{\mathrm{it}}
$$


Dimana:

$\begin{array}{ll}\text { PV }_{\text {it }} & \text { : Volatilitas Harga Saham } \\ \text { DER }_{\text {it }} & : \text { Leverage untuk perusahaan i di tahun } \mathrm{t} \\ \text { SIZE }_{\text {it }} & : \text { Ukuran perusahaan untuk perusahaan i di tahun } \mathrm{t} \\ \text { GROWTH }_{\text {it }} & : \text { Pertumbuhan aset untuk perusahaan i di tahun } \mathrm{t} \\ \mathrm{e} & : \text { Standar error }\end{array}$

\section{HASIL DAN PEMBAHASAN PENELITIAN}

Analisis statistik deskriptif digunakan untuk menjelaskan beberapa karakteristik data variabel-variabel penelitian terdapat dalam Tabel 1 sebagai berikut:

Tabel 1 Statistik Deskriptif

\begin{tabular}{lcccc}
\hline & PV & LEV & SIZE & Growth \\
\hline Mean & 0,1508 & 2,0431 & 31,8601 & 0,1111 \\
Median & 0,1474 & 0,9700 & 31,7119 & 0,0915 \\
Maximum & 0,2768 & 12,080 & 34,8150 & 0,5937 \\
Minimum & 0,0707 & 0,1400 & 28,7301 & $-0,1122$ \\
Std. Dev. & 0,0523 & 2,4435 & 1,4326 & 0,1312 \\
Observations & 93 & 93 & 93 & 93 \\
\hline
\end{tabular}

Sumber: Data olahan

Berdasarkan Tabel 1 di atas menunjukkan bahwa volatilitas harga saham terendah dalam kurun waktu 2017-2019 adalah 0,0707 pada tahun 2019 yang merupakan volatilitas harga saham PT Kalbe Farma Tbk. Sementara itu, volatilitas harga saham tertinggi adalah 0,2768 pada tahun 2019 yang merupakan harga saham PT Media Nusantara Citra Tbk. Rata-rata volatilitas harga saham sebesar 0,1508 dengan standar deviasi sebesar 0,0523. Rasio leverage terendah dalam kurun waktu 2017-2019 adalah 0,1400 pada tahun 2019 yang merupakan leverage PT Vale Indonesia Tbk., sedangkan leverage tertinggi adalah 12,080 pada tahun 2019 yang merupakan rasio leverage Bank Tabungan Negara Tbk. Rata-rata leverage sebesar 2,043 dengan standar deviasi sebesar 2,443. Selanjutnya, ukuran perusahaan terendah dalam kurun waktu 2017-2019 adalah 28,730 pada tahun 2017 yang merupakan ukuran perusahaan PT Aneka Tambang Tbk, sedangkan ukuran perusahaan tertinggi adalah 34,815 pada tahun 2019 yang merupakan ukuran perusahaan Bank Mandiri Tbk. Rata-rata ukuran perusahaan sebesar 31.8601 dengan standar deviasi sebesar 1,4236. Sementara itu, pertumbuhan aset terendah dalam kurun waktu 2017-2019 adalah -0.1122 pada tahun 2019 yang merupakan pertumbuhan aset PT Perusahaan Gas Negara Tbk, sedangkan pertumbuhan aset tertinggi adalah 0,5937 pada tahun 2017 yang merupakan pertumbuhan aset PT Waskita Karya Tbk. Rata-rata pertumbuhan aset sebesar 0,1112 dengan standar deviasi sebesar 0,1312.

Hasil uji regresi data panel dengan menggunakan fixed effect model (model efek tetap) ditunjukkan pada Tabel 2 sebagai berikut: 
Tabel 2 Hasil Uji Regresi

\begin{tabular}{crrrrl}
\hline Variable & Arah & Koefisien & \multicolumn{1}{c}{ T-test } & \multicolumn{1}{l}{ Prob } & \\
\hline C & & -1.2235 & -2.2977 & 0.0125 & $* *$ \\
Leverage (X1) & + & 0.0310 & 1.5282 & 0.0659 & $* * *$ \\
Firm Size (X2) & - & 0.0411 & 2.4395 & 0.0088 & $* * *$ \\
Asset Growth (X3) & - & -0.0106 & -0.2925 & 0.3854 & \\
R2 & 0.7088 & & & & \\
Adj. R2 & 0.5459 & & & & \\
F-stat. & 4.3521 & & & & \\
Prob(F-stat.) & 0.0000 & & & &
\end{tabular}

*** significant at the $1 \%$ level

**significant at the $5 \%$ level

*significant at the $10 \%$ level

Dari Tabel 2, variabel leverage memiliki nilai signifikansi $0,0659<0,1$ dengan taraf signifikansi $10 \%$. Koefisien variabel sebesar 0,0310 yang berarti jika faktor lain tidak berubah, maka setiap kenaikan 1 leverage akan menyebabkan kenaikan volatilitas harga saham sebanyak 3,1\%. Hal ini menunjukkan leverage berpengaruh positif signifikan terhadap volatilitas harga saham. Dengan demikian, hipotesis pertama $\left(\mathrm{H}_{1}\right)$ leverage berpengaruh positif signifikan terhadap volatilitas harga saham diterima. Ukuran perusahaan memiliki nilai signifikansi $0,0088<$ 0,05 dengan taraf signifikansi 5\%. Koefisien variabel sebesar 0,0411 yang berarti jika faktor lain tidak berubah, maka setiap kenaikan 1 ukuran perusahaan akan menyebabkan kenaikan volatilitas harga saham sebanyak 4.11\%. Hal ini menunjukkan ukuran perusahaan berpengaruh positif signifikan terhadap volatilitas harga saham. Dengan demikian, hipotesis kedua $\left(\mathrm{H}_{2}\right)$ ukuran perusahaan berpengaruh negatif signifikan terhadap volatilitas harga saham ditolak. Selanjutnya, pertumbuhan aset memiliki nilai signifikansi 0.3854 baik dengan taraf signifikansi 5\% maupun $10 \%$ nilai signifikansi variabel ini lebih besar dari kedua taraf signifikansi tersebut. Hal ini menunjukkan pertumbuhan aset tidak berpengaruh terhadap volatilitas harga saham. Dengan demikian, hipotesis ketiga $\left(\mathrm{H}_{3}\right)$ pertumbuhan aset berpengaruh positif signifikan terhadap volatilitas harga saham ditolak.

\section{Pengaruh Leverage terhadap Volatilitas Harga Saham}

Hasil uji hipotesis menunjukkan bahwa leverage berpengaruh positif terhadap volatilitas harga saham. Hasil pengujian ini sejalan dengan (Abrar-ul-haq et al. 2015; Jannah and Hariadhi 2016; Mobarak and Mahfud 2017; Selpiana and Badjra 2018). Tingkat leverage merupakan sinyal kepada investor atas risiko keuangan yang dihadapi oleh perusahaan. Perusahaan yang banyak melakukan pendanaan dengan utang memiliki risiko yang tinggi karena berpotensi memiliki masalah kesulitan keuangan akibat pembayaran bunga tetap yang terlalu besar. Perusahaan juga akan lebih memprioritaskan membayar hutang terlebih dahulu dibandingkan dengan membagikan dividen untuk para investor. Oleh karena itu, respon investor kurang baik terhadap perusahaan dengan tingkat leverage yang tinggi karena investor menganggap keberlangsungan perusahaan dipertanyakan. Respon tersebut tercermin dari tingkat ketidakstabilan harga saham yang tinggi. 


\section{Pengaruh Ukuran Perusahaan terhadap Volatilitas Harga Saham}

Hasil uji hipotesis menunjukkan bahwa ukuran perusahaan berpengaruh negatif terhadap volatilitas harga saham. Hasil pengujian ini sejalan dengan penelitian (Patriadjati 2017; Surahmat et al. 2017; Andiani and Gayatri 2018; Rusiana and Kusumawati 2019; Marini and Dewi 2019; Yulinda et al. 2020). Penelitian ini mengindikasikan adanya data perusahaan LQ-45 yang digunakan dalam penelitian ini rata-rata termasuk dalam kategori perusahaan besar. Perusahaan ini dianggap memiliki risiko yang rendah dibandingkan perusahaan diluar LQ-45. Perusahaan yang lebih besar memiliki kebijakan bisnis yang lebih stabil sehingga perusahaan ini dianggap lebih mapan dalam menghadapi kondisi di masa mendatang. Akibatnya, investor merespon positif perusahaan-perusahaan besar ini karena investor investor diduga lebih mempercayakan investasinya pada perusahaan-perusahaan dalam mencapai tingkat pengembalian yang diharapkan. Selain itu, karakteristik perusahaan-perusahaan besar meningkatkan keyakinan investor dalam pengambilan keputusan investasi di perusahaan tersebut karena perusahaan-perusahaan besar cenderung dianggap memiliki risiko yang rendah.

\section{Pengaruh Pertumbuhan Aset terhadap Volatilitas Harga Saham}

Hasil uji hipotesis menunjukkan bahwa pertumbuhan tidak berpengaruh terhadap volatilitas harga saham. Hasil pengujian ini sejalan dengan hasil penelitian (Rowena and Hendra 2017; Santioso and Angesti 2019). Penelitian ini mengindikasikan bahwa pertumbuhan aset bukan merupakan pertimbangan investor dalam memutuskan untuk berinvestasi. Investor tidak melihat bahwa perusahaan secara operasional berkembang dengan adanya pertumbuhan aset yang dimiliki. Teori pasar efisien $(\mathrm{EMH})$ menyatakan bahwa harga saham, volume dan frekuensi perdagangan saham yang terbentuk di pasar merupakan cerminan dari informasi yang ada. Seyogyanya investor akan bereaksi cepat terhadap informasi tersebut dan akan segera melakukan penyesuaian. Namun, informasi pertumbuhan aset tidak digunakan dalam pengambilan keputusan investor. Para investor lebih melihat seberapa aktif saham suatu perusahaan diperjualbelikan di pasar modal bukan berdasarkan tingkat pertumbuhan aset yang dimiliki perusahaan. Informasi pertumbuhan aset perusahaan tidak mampu memberikan sinyal kepada investor sehingga tidak mendapat reaksi pasar dan tidak mampu menjelaskan volatilitas harga saham.

\section{KESIMPULAN}

Penelitian ini menemukan bahwa terdapat pengaruh positif dari leverage terhadap volatlilitas harga saham. Perusahaan yang mempunyai tingkat leverage tinggi berarti menanggung risiko yang lebih besar apabila tidak mampu melunasi kewajibannya kepada kreditor. Tingkat leverage memberikan sinyal kepada investor atas risiko keuangan yang dihadapi oleh perusahaan. Ukuran perusahaan berpengaruh negatif terhadap volatilitas harga saham. Perusahaan yang semakin besar diduga memili strategi bisnis yang lebih baik, sehingga kondisi tersebut memberikan keyakinan kepada investor dalam menempatkan investasinya pada perusahaan tersebut. Selanjutnya, pertumbuhan aset tidak berpengaruh terhadap volatilitas harga saham. Pertumbuhan aset bukan merupakan pertimbangan investor dalam memutuskan untuk berinvestasi. Informasi pertumbuhan aset 
perusahaan tidak mampu memberikan sinyal kepada investor sehingga investor tidak merespon informasi tersebut.

Penelitian ini memiliki keterbatasan karena data yang digunakan dalam penelitian ini hanya menggunakan data dan informasi perusahaan yang termasuk indeks LQ-45, sehingga hasil penelitian ini tidak dapat menggenaralisir untuk data keseluruhan perusahaan di Indonesia. Selain itu, jumlah tahun penelitian hanya meliputi periode tiga. Oleh karena itu, penelitian selanjutnya dapat menguji kembali variabel-variabel yang digunakan dalam penelitian ini dengan menggunakan data perusahaan lainnya baik sektor keuangan maupun sektor non keuangan untuk membandingkan hasilnya dengan penelitian ini. Selain itu, penelitian selanjutnya dapat menggunakan time-horizon yang lebih panjang untuk mendapatkan data yang lebih mewakili kondisi yang sebenarnya.

Hasil penelitian ini dapat dijadikan bahan evaluasi bagi manajemen perusahaan yang memperdagangkan sahamnya di pasar modal untuk dapat mengontrol volatilitas harga saham melalui kebijakan leverage atau struktur modal yang ditetapkan. Selain itu, hasil penelitian ini dapat menjadi bahan evaluasi bagi investor dalam membuat keputusan investasi di pasar modal khususnya informasi yang bersumber dari laporan keuangan perusahaan.

\section{DAFTAR PUSTAKA}

Abrar-ul-haq, Muhammad, Kashif Akram, and Muhammad Imdad Ullah. 2015. "Stock Price Volatility and Dividend Policy in Pakistan". International Journal of Scientific and Research Publications 5 (2): 1-7.

Andiani, Ni Wayan Sekar, and Gayatri. 2018. "Pengaruh Volume Perdagangan Saham, Volatilitas Laba, Dividend Yield, dan Ukuran Perusahaan Pada Volatilitas Harga Saham". E-Jurnal Akuntansi 24 (3): 2148-2175. https://doi.org/10.24843/EJA.2018.v24.i03.p19.

Ardiansyah, Ivan, and Yuyun Isbanah. 2017. "Analisis Pengaruh Deviden, Pertumbuhan Aset, Ukuran Perusahaan, Dan Leverage Terhadap Volatilitas Harga Saham". Jurnal Riset Akuntansi Dan Keuangan 5 (3): 1565-1574.

Artikanaya, I Kadek Rama, and Gayatri. 2020. "Pengaruh Asset Growth, Leverage, dan Dividend Payout Ratio pada Volatilitas Harga Saham”. E$\begin{array}{lllll}\text { Jurnal } & \text { Akuntansi } & 30 & \text { (5): } & \text { 1270-1282. }\end{array}$ https://doi.org/10.24843/EJA.2020.v30.i05.p16.

Bahrun, Muhammad Fadly, Tifah, and Amrie Firmansyah. 2020. "Pengaruh Keputusan Pendanaan, Keputusan Investasi, Kebijakan Dividen, Dan Arus Kas Bebas Terhadap Nilai Perusahaan". Jurnal Ilmiah Akuntansi Kesatuan 8 (3): 263-276. https://doi.org/10.37641/jiakes.v8i3.358.

Dewi, Ni Made Ayu Krisna, and I Gst Ngr Agung Suaryana. 2016. "Pengaruh Volume Perdagangan Saham, Leverage, Dan Tingkat Suku Bunga Terhadap Volatilitas Harga Saham”. E-Jurnal Akuntansi 17 (2): 11121140 .

Dissanayake, Sulochana, and Mihiri Wickramasinghe. 2016. "Earnings Fluctuation On Share Price Volatility". Account and Financial Management Journal, 1 (5): 360-368. 
Fahmi, Irham. 2016. "Manajemen Investasi: Teori dan Soal Jawab”. Jakarta: Salemba Empat.

Firmansyah, Amrie, and Vinola Herawaty. 2016. "Pengaruh Income Smoothing, Kebijakan Deviden, Leverage dan Ukuran Perusahaan Terhadap Earnings Response Coefficient dan Future Earnings Response Coefficient". Jurnal Informasi, Perpajakan, Akuntansi, Dan Keuangan Publik 11 (1): 31-48. http://dx.doi.org/10.25105/jipak.v11i1.4568.

Firmansyah, A., and Yunidar, A. 2020. "Financial Derivatives, Financial Leverage, Intangible Assets, And Transfer Pricing Aggressiveness: Evidence From Indonesian Companies". Jurnal Dinamika Akuntansi dan Bisnis 7 (1): 1-14.

Jannah, Raudhatul, and Musfiari Haridhi. 2016. "Pengaruh Kebijakan Dividen, Earning Volatility, Dan Leverage Terhadap Volatilitas Harga Saham Pada Perusahaan Non-Financing Yang Terdaftar Di Bursa Efek Indonesia Tahun 2010-2014". Jurnal Ilmiah Mahasiswa Ekonomi Akuntansi (JIMEKA) 1 (1): 133-148.

Mahdy, A. A. 2015. "Faktor-faktor yang mempengaruhi volatilitas harga saham pada perusahaan-perusahaan konsumsi yang terdaftar di Bursa Efek Indonesia". Jurnal Akuntansi dan Bisnis 1 (1): 97-111.

Marini, Ni Luh Putu Sintya, and Sayu Ketut Sutrisna Dewi. 2019. "Pengaruh Kebijakan Dividen, Leverage, Dan Ukuran Perusahaan Terhadap Volatilitas Harga Saham". E-Jurnal Manajemen 8 (10): 5887-5906. https://doi.org/10.24843/EJMUNUD.2019.v08.i10.p01.

Mobarak, Rizqin, and Mohammad Kholiq Mahfud. 2017. "Analisis Pengaruh Kebijakan Dividen, Bvps, Earning Volatility, Leverage, Per, Dan Volume Perdagangan Terhadap Volatilitas Harga Saham (Studi Empiris Pada Perusahaan Go Public Non Keuangan Yang Listing Di Bursa Efek Indonesia Tahun 2012-2015)". Diponegoro Journal of Management 6 (2): $1-13$.

Murniati, Sitti 2015. "Faktor-Faktor Yang Berpengaruh Terhadap Harga Saham Perusahaan Makanan Dan Minuman Yang Terdaftar Di Bursa Efek Indonesia". Jurnal Aplikasi Manajemen 9 (3): 137-144.

Mustika, Julisa. 2018. "Faktor-Faktor Yang Mempengaruhi Volatilitas Harga Saham”. Skripsi: Fakultas Ilmu Ekonomi dan Bisnis, Institut Informatika dan Bisnis Darmajaya.

Nasution, Yenni Samri Juliati. 2015. "Hypothesis Pasar Efisien/Efficient Market Hypothesis". Jurnal Perspektif Ekonomi Darussalam 1 (1): 25-43.

Oktavianti, Rika, and Saryadi. 2020. "Pengaruh Dividend Payout Ratio, Firm Size, Dan Leverage Terhadap Volatilitas Harga Saham (Studi Pada Perusahaan Indeks LQ-45 Yang Terdaftar Di Bursa Efek Indonesia Periode 2016-2018)". Jurnal Ilmu Administrasi Bisnis 9 (2): 119-132.

Pajriansyah, Ridwan, and Amrie Firmansyah. 2017. "Pengaruh Leverage, Kompensasi Rugi Fiskal Dan Manajemen Laba Terhadap Penghindaran Pajak". Keberlanjutan 2 (1): 431-459.

Patriadjati, R. M. M. S. 2017. “Analisis Dampak Penentuan Dividend Yield, Firm Size, Growth In Assets Dan Earnings Volatility Pada Stock Price Volatility: Perusahaan-Perusahaan Yang Menerbitkan Sekuritas Dalam 
Bursa Efek Indonesia”. Skripsi: Fakultas Ekonomi dan Bisnis, Universitas Muhammadiyah Yogyakarta.

Rohmawati, Irma. 2016. "Pengaruh Volume Perdagangan, Dividend Payout Ratio

Dan Inflasi Terhadap Volatilitas Harga Saham Pada Perusahaan Yang

Terdaftar Dalam Indeks LQ45 Tahun 2011-2015”. Skripsi: Fakultas

Ekonomi, Universitas Negeri Yogyakarta.

Rowena, Janny, and Hendra. 2017. "Earning Volatility, Kebijakan Dividen, Dan Pertumbuhan Asset Berpengaruh Terhadap Volatilitas Harga Saham Pada Perusahaan Manufaktur Di BEI Periode 2013-2015". Jurnal Administrasi Kantor 5 (2): 231-242.

Rusiana, I., and R. Kusumawati. 2019. "Analisis Pengaruh Kebijakan Dividen, Leverage, Ukuran Perusahaan, Nilai Tukar Mata Uang, Tingkat Suku Bunga Dan Inflasi Terhadap Volatilitas Harga Saham”. Working Paper: Fakultas Ekonomi dan Bisnis, Universitas Muhammadiyah Yogyakarta.

Salman, Irham, Amrie Firmansyah, and Meicha Rizka Widyaningrum. 2020. "Peran Leverage Sebagai Pemoderasi: Revaluasi Aset Tetap, Kebijakan Dividen, Nilai Perusahaan”. Jurnal Magister Akuntansi Trisakti 7 (2): 171-190.

Santioso, Linda, and Yosevin Gloria Angesti. 2019. "Faktor-Faktor Yang Mempengaruhi Volatilitas Harga Saham”. e-JE: Jurnal Ekonomi, 24 (01): 46-64. http://dx.doi.org/10.24912/je.v24i1.450.

Selpiana, Komang Ria, and Ida Bagus Badjra. 2018. "Pengaruh Kebijakan Dividen, Nilai Tukar, Leverage, Dan Firm Size Terhadap Volatilitas Harga Saham”. E-Jurnal Manajemen $7 \quad$ (3): $1682-1712$. https://dx.doi.org/10.24843/EJMUNUD.2018.v7.i03.p20.

Surahmat, Fifi Swandari, and Dian Masita Dewi. 2017. "Pengaruh Kebijakan Dividen Dan Faktor Lainnya Terhadap Volatilitas Harga Saham Perusahaan Pertambangan". JWM (Jurnal Wawasan Manajemen) 5 (2): 201-216.

Theresia, Priskilla, and Erika Jimena Arilyn. 2015. "Pengaruh Dividen, Ukuran Perusahaan, Hutang Jangka Panjang, Earning Volatility, Pertumbuhan Aset, Trading Volume, Dan Volatilitas Harga Saham”. Jurnal Bisnis dan Akuntansi 17 (2): 197-204.

Waluyo, W. 2016. “Analisis Determinan Volatilitas Harga Saham (Studi Pada Perusahaan Yang Terdaftar Dalam Indeks LQ45)”. Skripsi: Fakultas Ekonomi, Universitas Negeri Yogyakarta.

Yulinda, Eva, Triani Puji Astuti, and S. T. Haryono 2020. "Analisis pengaruh dividend payout ratio, leverage, firm size, volume perdagangan, earning volatility dan inflasi terhadap volatilitas harga saham pada perusahaan yang terdaftar dalam indeks LQ45 tahun 2014-2017”. Syntax Literate: Jurnal Ilmiah Indonesia 5 (5): 76-83. http://dx.doi.org/10.36418/syntaxliterate.v5i5.1106. 